Notas Clínicas

\title{
Giant residual non-seminonatous mediastinal mass
}

\author{
A. Ocaña, E. Ceballos, G. Marcos, G. Martín, J. J. Cruz
}

\section{Summary}

- Purpose: To point out the difficult therapeutic management of mediastinal germ-cell tumors and the residual masses.

- Material and methods: We present a patient with a mediastinal non-seminomatous germcell tumor and the therapeutic management of the residual mass.

- Results and conclusion: Surgical resection is the therapeutic attitude with regard to a residual non-seminomatous mediastinal mass.

Key words: Mediastinal mass. Germ-cell tumor. Residual mass.

Oncología, 2004; 27 (3):140-142

\section{Resumen}

- Propósito: destacar el difícil manejo terapéutico de los tumores germinales mediastínicos y de las masas residuales postquimioterapia.

- Material y Métodos: se presenta el caso de un paciente con un tumor germinal no seminomatoso mediastínico y el manejo terapéutico de la masa residual.

- Conclusiones: ante una masa residual no seminomatosa mediastínica con marcadores negativos la actitud terapéutica es la quirúrgica.

Palabras clave:

Masa mediastínica. Tumor germinal. Masa residual. 


\section{Introducción}

Primary mediastinal non-seminomatous germ-cell tumors are rare neoplasms. The incidence is evaluated about half that of extra-gonadal germ cell tumors and it occur in young male adults. Their treatment is general based on protocols used for germ testicular cancer. These tumors have a poor prognosis due, in part, to their bulk and relative chemosensitivity, but also due in part to their association with non-Germ cell elements and hematologic malignancies.

Malignant nonseminomatous germ cell tumors are primary treated with chemotherapy and adjuvant surgery are reserved for patients with residual mediastinal masses after systemic therapy because of the possibility of residual viable tumor.

We report the case of a giant residual non-seminomatous mediastinal mass in a young male adult after systemic chemotherapy.

\section{Case report}

A 16 year- old- man came to our institution with chest pain, cough, fever and $3 \mathrm{~kg}$ weight loss in the last month. Physical examination was normal. A chest $X$-ray showed an enlarged mediastinum. A computed tomography scan showed a $14 \times 27 \times 22 \mathrm{~cm}$ mediastinum mass with desviation of mediastinum structures and did not shown any retroperitoneal mass. The PAAF of the mass was compatible with a germ cell tumor. Testicular and abdominal ecography were normal and serum markers were elevated. (AFP: 511, BHCG: 677).

The patient was therefore as having a mediastinum nom-seminomatous germ cell tumor. We started a chemotherapy treatment with cisplatin $20 \mathrm{mg} / \mathrm{m} 2$ plus Etoposido $100 \mathrm{mg} / \mathrm{m} 2$ day 1 and 5 plus Bleomicin 30 mg day 2, 9 and 16 each 21 days. After the 4 cycle the serum markers were still elevated and we changed a second line chemotherapy treatment with Ifosfamide $1.2 \mathrm{gr} / \mathrm{m} 2$ plus Cisplatin $20 \mathrm{mg} / \mathrm{m} 2$ day 1 till 5 plus Vinblastina $0.11 \mathrm{mg} / \mathrm{m} 2$ day 1 till 2 each 21 days. Serum markers were normal after the 2 cycle and the surgical excision were desestimated by the thoracic surgery department. Strict observation was performed and 6 months later we observed a serum markers elevation and a mediastinum mass progression. We tried a Cisplatin plus Etoposido regimen to reduce the mass. After two regimens without response surgical resection was the only available possibility. The surgical resection piece were informed as a necrotic and fibrosis mass with no tumor evidence of one and a half kilogram weight.

\section{Discussion}

Mediastinal germ cell tumors appear predominant in the anterior mediastinum and frequently present as a very large mass with local compression. Symtoms are typically vague and represent the local mass effects of the tumour ${ }^{6}$.

Chest computed tomography and examination of serum markers provides the critical workup before a tissue diagnosis is obtained.

Mediastinal NSGCT does not respond as well to chemotherapy, relapse more frequently and have the worst survival ${ }^{3}$.

It is difficult to predict the probability of persistent teratoma or of viable tumor in patients with normalized tumor markers and a normal CT scan following chemotherapy. Recommendations ranged from observation to surgical exploration for all patients.

Suggested variables for patients in whom surgery can be omitted safely include normal post-chemotherapy $\mathrm{CT}$ scans, residual abdominal masses of less than $1.5 \mathrm{~cm}$, a $90 \%$ or greater decrease in the volume of the retroperitoneal mass with chemotherapy and teratomatous elements in the orchiectomy specimen. In contrast, during several investigation, the application of the above mentioned criteria resulted in a false negative prediction of approximately $20 \%$. And in some studies no factors has been identified for residual lung or mediastinal mass that could be used to select a group of patients who could safely avoid surgery $1,2,4,5$.

If serum markers have normalized after chemotherapy, resection of all residual abnormalities on imaging studies of the mediastinum is recommended 2,3 . But in two studies surgical resection with elevated serum markers are recommended to prevent chemoresistance 7,8 .

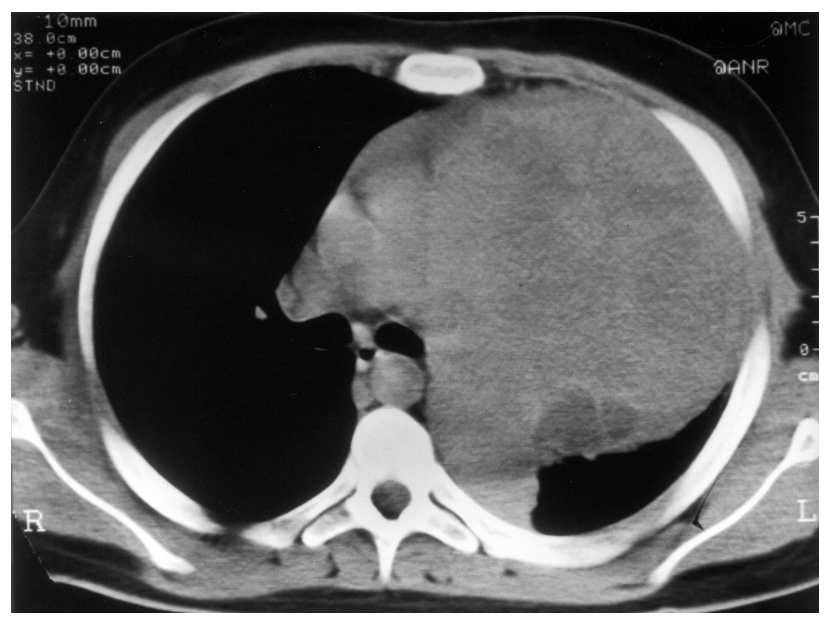

Fig. 1. 


\section{A. Ocaña y cols.}

In our case the persistence of a mass after chemotherapy without elevation of serum markers and without surgical resection available made us maintain a strict observation attitude. Six months later we observed an elevation of serum markers and a progression of the mediastinal mass. We started a Cisplatin and Etoposid chemotherapy regimen triaing to reduce the mass. After two regimens without response surgical resection was the only available possibility. The surgical resection piece were surprised informed as a necrotic and fibrosis mass of one and a half kilogram weight.

Patients who are serum tumor markers -negative but have radiographic evidence of residual disease are commonly seen. We showed a less frequent case of a residual giant fibrotic mass without tumor evidence and serum markers elevation.
Correspondencia:

Dr. A. Ocaña Fernández

Servicio de Oncología Médica

Hospital Universitario de Salamanca

Paseo San Vicente, 58-182

E-37007 Salamanca

\section{Bibliograph}

1. Kuczyk M, Machtens S, Stief C, et al. Management of the post-chemotherapy residual mass in parients with advanced stage non-seminomatous germ cell tumors. Int J Cancer. 1999; 10;83:852-5.

2. Toner GC, Panicek DM, Heelan RT, et al. Adjuntative surgery after chemotherapy for nonseminomatous germ cell tumors recommendations for patient selection. J Clin Oncol. 1990; 8:1683-94.

3. Toner GC, Geller NL, Lin SY, et al. Extragonadal and poor risk nonseminomatous germ cell tumors. Survival and prognostic features. Cancer. 1991; 67:2049-57.

4. Steyerberg EW, Keizer HJ, Fossa SD, et al. Prediction of residual retroperitoneal mass histology after chemotherapy for metastatic nonseminomatous germ cell tumor: multivariate analysis of individual patient data from six study groups. J Clin Oncol. 1995; 13:1177-87.

5. Steyerberg EW, Keizer HJ, Messemer JE, et al. Residual pulmonary masses after chemotherapy for nonseminomatous germ cell tumor. Cancer. 1997; 79:345-355.

6. Geoffrey B. Blossom, Zwi Steiger, Larry W. Stephenson. Neoplasm of the mediastinum. Cancer: Principles and practice of Oncology, Fifth Edition, edited by Vincent T. DeVita, Jr Samuel Hellman, Steven A. Rosenberg. Lippincott-Raven Publishers, Philadelphia 1997; 963-964.

7. Bukowski RM, Wolf M, Kulander BG, et al. Alternating combination chemotherapy in patientes with extragonadal germ cell tumors. Cancer 1993; 71:2631-2638.

8. Bower M, Brock C, Holden L, et al. POMB/ACE chemotherapy for mediastinal germ cell tumours. Eur J Cancer 1997; 33:383-842. 